\title{
Countermeasures and Influencing Factors of Minority Preparatory English Class
}

\author{
Hongxia Dai \\ Ethic School, Nanchang Institute of Science and Technology \\ Nanchang 330108, China \\ dhx8522@163.com
}

\begin{abstract}
Due to the self-development requirements of minority preparatory students and the requirements for the development of schools and society, minority preparatory teachers must achieve the goal of improving the effectiveness of the English class. The paper will discuss countermeasures and influencing factors of the minority preparatory English class in terms of school, teachers and students. Studies have shown that classroom effects have always been the focus of schools, teachers and preparatory ethnic minority students. High quality English class effect can improve English teaching and better develop minority preparatory students' abilities of English study and cultivate their interest in learning English. This paper discusses the countermeasures and influencing factors in English class for minority preparatory students, and hopes that related researchers will benefit from it.
\end{abstract}

Keywords-Minority Preparatory Students; English; Influence Factors; Teacher; Class influence

\section{INTRODUCTION}

Class teaching is the main way of school work. Teaching is the lifeline of sustaining school and school's reputation. Nowadays old teaching style is difficult to be appropriate for present minority preparatory students. School must adopt to be student-oriented teaching, especially, educators advocate education need reform in recent year. Therefore, the effects of a class must be emphasized. The effects of a class can be mirrored by the student's class performances. The effect of a class affects a lot, such as minority preparatory students' learning interest, reputation of school, teacher's teaching passion, etc.. However, the high-quality English class is influenced by many factors. I will expound the minority preparatory English class influence factors and countermeasures from school, teachers and students.

\section{FROM SCHOOL'S PERSPECTIVE}

It can not be ignored that school plays an important role in minority preparatory English class because the school is the big family of the students. It is generally believed that family is essential to a child's growth. Family must provide a good environment for the child if they want the child to make the way in the world. By the same token, as a big good family, school must create a harmonious learning atmosphere. In my three-year minority preparatory students teaching experience, I feel deeply that school environment have a big impact on the minority preparatory students' English class. Since last year,

Foundation program: Teaching Reform Research Project of Nangchang

Institute of Science and Technology: Countermeasures and Factors of

Minority Preparatory English Class Influence (NGJG-16-16). our school has emphasized the importance of teaching quality. The school stipulates that the approval of students' leave of absence can't be allowed so easily as the formalities must follow according to the school's rules. After our school met the assessment of Ministry of Education in 2017, our school emphasized the effect of class better. There is a strict watch and supervision over students' absenteeism, mobile phones' uses and sleeping in class. Before class begins, students must be handed in their phone in stipulated placed. At first, students are unwilling to do this, but students are unwilling to hand in their telephones to mobile phone's bags in a short time. The school demands the teachers' cooperation in proof of written request for leave which must be put in the record of the monitors, or send the picture of it to English teachers. It is also stipulated that the number of leaves, absenteeism should be reported to the school on Tuesday before knocking off. Additionally, Teachers from our school of ethnic often inspects the effect of a class, and the school of ethnic will deal with the problems according to the school's relative rules. Through this way, the school of ethnic offers a good learning environment, making more students present in English class and reducing the number of students playing with mobile phones in class as well as sleeping students in class. There is a good phenomena that students make the class rule: students who want to sleep have to stand a while or to leave for restroom for washing their faces so that they can refresh themselves .According to the presentation of above, it can conclude that the school management matters a lot in providing a healthy learning atmosphere. Leaders must consider the school management when they decide how to improve English class effect of minority preparatory students. As figure shows:

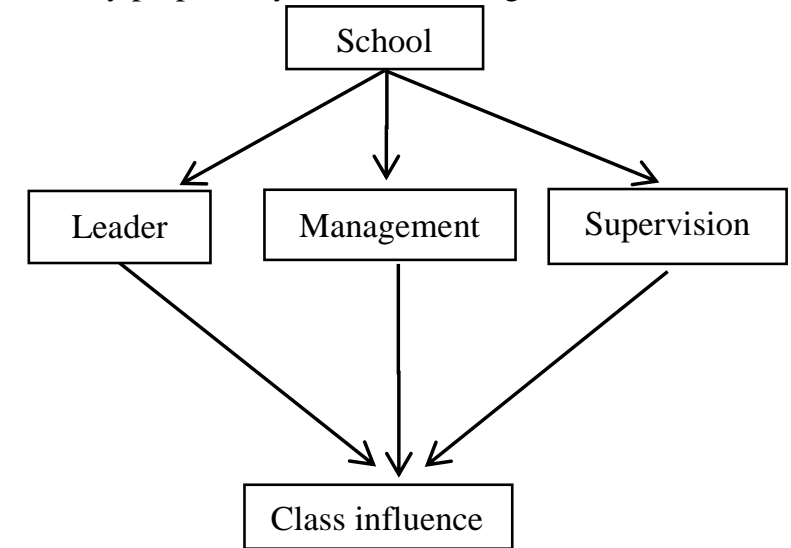

Fig. 1 From School's Perspective 


\section{FROM THE TEACHER'S PERSPECTIVE}

Teacher is another important factor influencing English class for minority preparatory students. The teachers can influence class in many ways: firstly, the spiritual manner or air. The teacher's mental attitudes can have a big influence on the minority preparatory students. As it is put, "touch pitch and you will be defiled". Supposing a teacher with high spirit and passion gives minority preparatory students a class, the class effect can be good and satisfied without doubt, which can stimulate minority preparatory students to study hard and teachers will be willing to teach them. Even those students who are not interested in class at first can be involved in the class as well in the long run. On the contrary, a teacher without passion gives minority preparatory students class, they may fall in sleep slowly or lost interest in the class because the class is boring and dull, sometimes, even lost interested in English learning. Therefore, rather than bring the bad emotions to class, teachers must pay more attention to the spiritual manners so as to enhance the class efficiency for minority preparatory students.

Secondly, teachers must have sound major knowledge. As the sayings go, "One minute on stage takes ten years of practice." And "To give students a glass of water, the teacher should have a bucket of water". If a knowledge point is not fully understood by the teacher, how he or she can teach the students. Teachers must study on their own or other ways as long as they have time, especially they have winter or summer holidays. Additionally, to get ideal class effect, teachers need master the mental condition of minority preparatory students. Because they are from different places some minority preparatory students have psychic problem to English study. Therefore, the teacher must read the relative books in their spare time to improve their abilities so that they will have good class effect during teaching minority preparatory students.

Thirdly, teachers should be paid attention to their chalk writing which can affect minority preparatory students' studying effect, too. Teachers should use chalks with different colors to lay stress on the important language points. It's monotonous for minority preparatory students to look at words with single white chalk. Good chalk handwriting can not only attract minority preparatory students but also make them like looking blackboard so that they can remember some important language point written on blackboard by their teacher. In fact, Good chalk handwriting is an important basic skill for an excellent teacher. Therefore, the class efficiency can be enhanced accordingly as long as teachers put emphasis on this point.

Fourthly, the teacher must make good preparations without making good preparations, one can not give a good lesson just like waging a battle without preparations. The teacher must not only prepare oneself, but also prepare the teaching materials and prepare for the students. To make a full preparation, teacher must understand the teaching material to know the teaching objectives, for example, how to present the teaching contents in class and how to achieve the teaching objectives. To prepare for the students, teacher must be familiar with the students' different conditions, anticipating the mistakes, the difficult points and forgettable contents. Minority preparatory students are from different ethnic minority, so their
English foundation are different, too. Different ethnic minorities have different policies to English. Few minority preparatory students are zero foundation because they don't study English rather than Japanese. However, they must learn English in ethnic school. Teachers should consider these factors. As long as the teacher takes those factors into consideration, he can have a better control of the class. In addition, the teacher must prepare oneself such as to check whether the teaching plan is prepared, how to organize the class, whether the teaching content is familiarized with. One also need to consider whether there is place left to be improved. Especially, the last teaching summary must be reread to gain lesson. A famous teacher said: If one wants to be an excellent teacher, one must write class conclusion after every class, hence, writing class conclusion is also important, too. In a word, the teacher must make a full preparation before class so as to achieve the desired effects.

Fifthly, the teacher should be equipped with good teaching organizing ability. The teacher should prepare how to present the teaching content like what comes first and what next before the class. Before class, the teacher is supposed to deal with the unexpected and know when the students can easily accept the difficult knowledge points. When ethnic students feel tiered teachers can explain some easy language points or play a game or speak a joke or read tongue twists or listen an English song, which make them feel relax, then make them study a little difficult language points. In class, the teacher should combine peace and move, thick and thin, tense and relax. Consequently, to improve the teachers' organizing abilities is a way to enhance the effects of the minority preparatory class.

Sixth, the teacher must help stimulate the English interest of the students. As it is put, "interest is the best teacher. Whatever it is, interest can lead to a success. The teacher should help students set learning goals including small aims so that they can possess a sense of fulfillment, keeping the interest continuing. Interest is the inner motivation of minority preparatory students. It looks as if Learning English fall in love with somebody. If minority preparatory students really love learning English, they will try their best to learn English. Interest and hardworking and adapt learning method will help them learn English well. Therefore, cultivating interest is the key of learning English well for them.

Last but not the least, a good relation must be built between the minority preparatory students and the teacher. The harmonious relation will bring a relaxing learning atmosphere in which the students are more willing to learn English. Therefore, how to set a good relationship between minority preparatory students and the teacher? To start with, Teachers should make minority preparatory students feel teachers' love for them and they have a good mood to study and live. Therefore, the teacher should love the minority preparatory students. Then the teacher must contact them, knowing their living styles and learning to know what they are thinking and get involved into their life. In class, teachers should pay attention to the content which must be related to realistic life. Otherwise it's difficult for them to master content explained by teachers and it's difficult for them to review. Teacher should encourage minority preparatory students to answer questions, even they get wrong answers, teacher must make use of active 
words to motivate them and don't prejudice them. Teacher should ask minority preparatory students with poor English to answer easy questions, therefore, teachers should make minority preparatory students to take part in English class and make them feel existence and sense of achievement. In reality, quite a few minority preparatory students prefer a class just because they like the teacher. At last, teachers should set reasonable goals for minority preparatory students. According to different minority preparatory students, teachers have different goals for them, which are accepted for them. Therefore, teachers can make full use of this point to improve their teaching class effects.

Part three as figure shows:

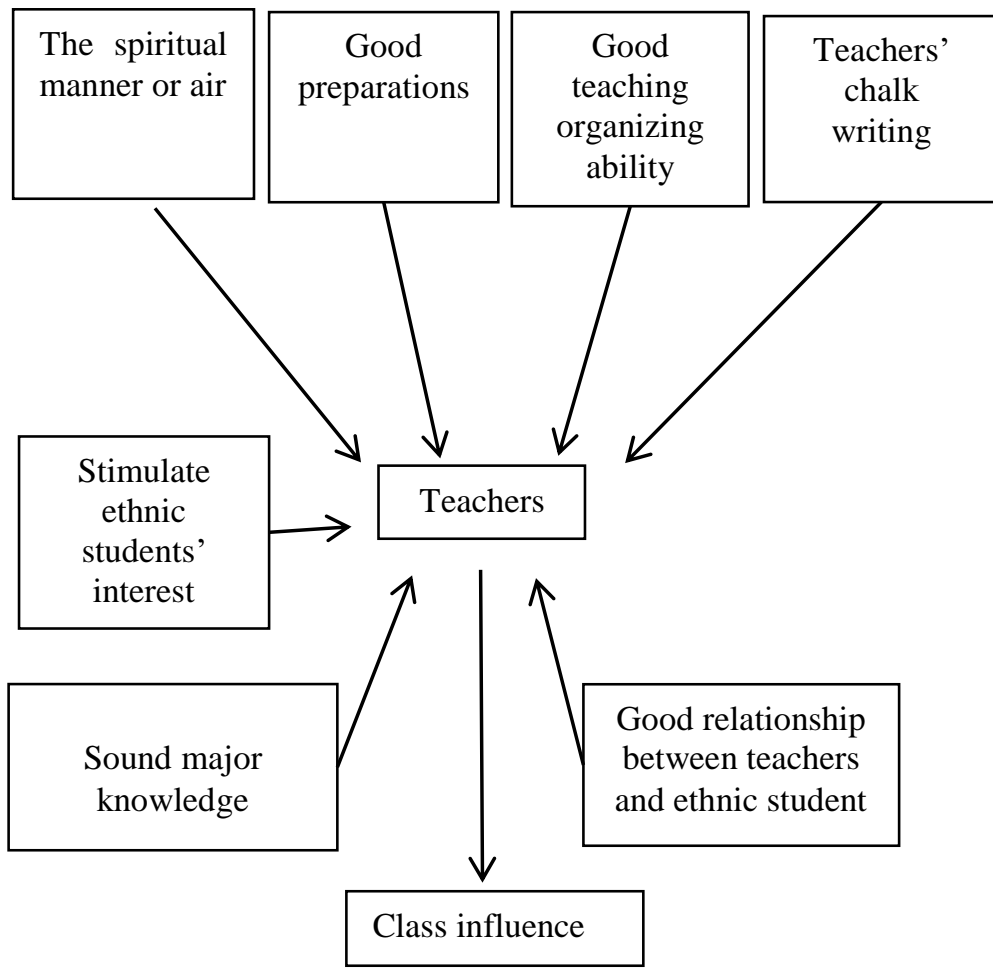

Fig. 2 From Teacher's Perspective

\section{From THE STUDENTS’ PERSPECTIVE}

Our country advocates the concept "human foremost" which can be put into the use of class. The class must be student- oriented for they are masters of class. Now, the class is not dominated by the teacher who should get the minority preparatory students involved in the class. To want to get better class influence, it also requests the minority preparatory students to do the followings:

First, the minority preparatory students must know the English requirement demanded by the school, the teacher and themselves. Once they have the goals in mind, they will strive for it. As it is put, "it is always contrary wind for a boat without direction". Many a student often complains, "I am busy everyday, however, I don't know what I have done and one day has been idled away". The minority preparatory students should know their own English goals like passing the English exam, communicating with foreigners, reading English papers and learning about English countries' cultures and so on. They must know that the big goal can be broken down into small aims and know how to achieve them one by one. After realizing the small aims, they can have a sense of achievement so that the confidence of learning English can be build.

Second, the minority preparatory students must preview the text before class. By comparison, they have a weak English foundation. Even few students have never studied English. The previewing can help them know about the contents by understanding where they should pay more attention so as to avoid some places not fully understood. If they don't preview what will learn in class their class effect is not good. As the old saying goes, "forewarned is forearmed" it shows previewing play an important part in enhancing the class efficiency and I hope minority preparatory students can realize the importance of previewing, then they know how to carry out.

Third, the minority preparatory students must review the lesson, as Confucius put it, "A man is worthy of being a teacher who gets to know what is new by keeping fresh in his mind what he is already familiar with.". According to the forgetting curve of the psychologist H.Ebbinghaus, human's forgetting speed is fast at first and slow then. The observation of the curve can make one find that the knowledge learnt the day before will be left only $25 \%$ if the review is not followed. With the passage of time, the forgetting speed is slowing down and the forgetting quantity is dropping accordingly. As a result, reviewing is an important factor in enhancing the class effect.

Part four as figure shows:

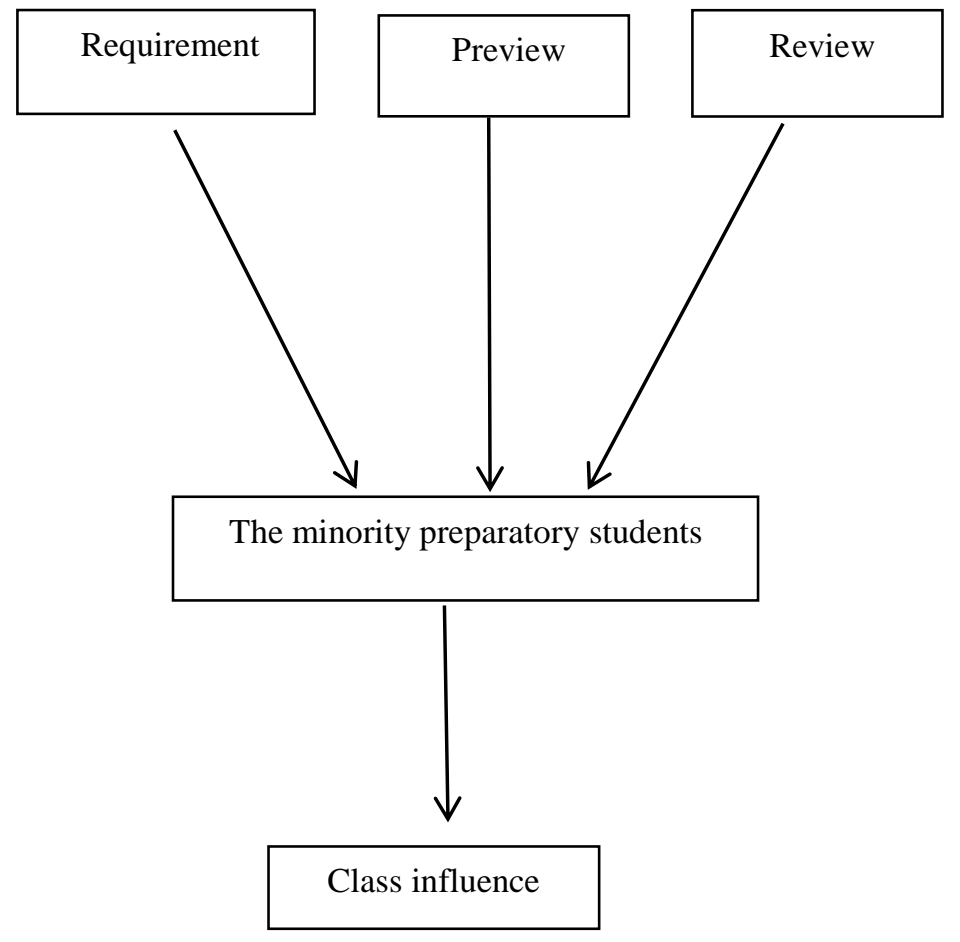

Fig. 3 From Students' Perspective 


\section{CONCLUSION}

Class influence is always the focus problem for the school, the teacher, the minority preparatory students, society and Ministry of Education. High quality English class effect can improve English teaching and better cultivate minority preparatory students' abilities of English study and interest in English, which meets the requirement of social circles. This paper discusses the countermeasures and influencing factors in English class for minority preparatory students with the hope that the readers can benefit from it.

\section{REFERENCES}

[1] Wang Hui. An Enquiry into the good class atmosphere creation. Journal of New Education Times [J], 2015.

[2] Li Zhihong. Create A Good Class Atmosphere to Enhance the Effect. Education Circle [J]. 2016.

[3] Lin Tingting, Create Good atmosphere to Improve Teaching Education. Education and Study of Guangdong. Vocational Technology [J]. 2012.

[4] $\mathrm{Zu}$ baoren. Theory on modern teacher qualities. Zhejiang University press $[\mathrm{M}] .2004$.

[5] Xu Hui, Zhang Yuanlong. Teachers' gain. Zhejiang University press [M]. 2004.

[6] Peng meiyun. Suggestion on class effect of Undergraduate Teaching. Chinese University Teaching [J]. 2010. 